\title{
Hydrological and physico-chemical dynamics in two Andean streams
}

\author{
Alejandro Sosnovsky1,, ${ }^{1}$, Magalí Rechencq ${ }^{1}$, María Valeria Fernández ${ }^{1}$, María José Suarez ${ }^{2}$ \\ and Rodolfo Juan Carlos Cantet2,3 \\ ${ }^{1}$ Grupo de Evaluación y Manejo de Recursos Ícticos, INIBIOMA, Universidad Nacional del Comahue, CONI- \\ CET, Quintral 1250, R8400FRF San Carlos de Bariloche, Argentina. \\ 2 Departamento de Producción Animal, Facultad de Agronomía, Universidad de Buenos Aires. Av. San Martín \\ 4453, C1417DSQ Ciudad Autónoma de Buenos Aires, Argentina. \\ 3 INPA, Universidad de Buenos Aires, CONICET. Chorroarín 280, C1427CWO Ciudad de Buenos Aires, \\ Argentina. \\ * Corresponding author: alejandro.sosnovsky@comahue-conicet.gob.ar
}

Received: $16 / 10 / 18$

Accepted: 25/02/19

\begin{abstract}
Hydrological and physico-chemical dynamics in two Andean streams

Discharge (Q) is an essential variable to understand how fluvial ecosystems function. To this aim, we assessed the hydrological and physico-chemical dynamics of two contrasting streams in Andean Patagonia: Casa de Piedra (CP) and Gutiérrez (G). CP originates in a small lake $\left(0.15 \mathrm{~km}^{2}\right)$ situated at high-elevation, whereas the source of $\mathrm{G}$ is a large $\left(17 \mathrm{~km}^{2}\right)$ piedmont lake. There are other differences between the drainage basins of these streams: CP drainage basin covers $63 \mathrm{~km}^{2}$ and slopes steep $(33.9 \mathrm{~m} / \mathrm{km})$, while that of $\mathrm{G}$ is bigger $\left(162 \mathrm{~km}^{2}\right)$ and gentler $(5.9 \mathrm{~m} / \mathrm{km})$. The current research was carried out over a period of 1 year. Variables measured were precipitation and temperature, as well as hydrological data $(\mathrm{Q}=$ discharge, $\mathrm{EC}=$ electrical conductivity, water temperature, turbidity and $\mathrm{pH}$ ). The climate and topography of the region led to 3 distinct hydrological periods: stormflow, meltflow and baseflow. Discharge presented a clear seasonal pattern with higher values at meltflow, due to snow melting from the mountains. Stream CP was very flashy (high variation in flow regime), unlike stream G. The greatest flashiness was observed during the stormflow period. Baseflow was characterised by low values of $Q$. The temperature of water fluctuated between the different hydrological periods and between the study streams, whereas $\mathrm{pH}$ varied seasonally only. Great turbidity in the streams was observed during the stormflow period, as a result of high run-off. Throughout the year, the relation between $\mathrm{Q}$ and $\mathrm{EC}$ in $\mathrm{CP}$ revealed different hydrological flowpaths towards the stream: flows derived from melting snow, lateral flows through the landscape and groundwater flows. In contrast, EC in stream G was high and constant during the whole recording period, independently of $\mathrm{Q}$. This indicates that the large headwater lake is its main source of water. This lake clearly affected the physico-chemical dynamics of stream G. In brief, the current research brought new knowledge into the ecological aspects of hydrological processes acting on the Andean-Patagonian aquatic ecosystems. On the basis of the results presented here and on expected future trends, we believe that the hydrological and physico-chemical dynamics of these ecosystems will be highly affected by climate change.
\end{abstract}

Key words: Patagonia, discharge, electrical conductivity, hydrological periods

\section{RESUMEN}

\section{Dinámicas hidrológicas y fisico-químicas en dos arroyos de la región andina}

El caudal $(Q)$ es una variable esencial para comprender el funcionamiento de los ecosistemas fluviales. En este trabajo estudiamos las dinámicas hidrológicas y físico-químicas de dos arroyos contrastantes de la Patagonia, el arroyo Casa de Piedra (CP) y el Arroyo Gutiérrez (G). El arroyo CP nace en un pequeño lago de altura $\left(0.15 \mathrm{~km}^{2}\right)$, en cambio el arroyo $G$ nace a partir de un gran lago $\left(17 \mathrm{~km}^{2}\right)$ de piedemonte. Además, existen otras diferencias entre sus cuencas de drenaje: la cuenca del arroyo CP es pequeña $\left(63 \mathrm{~km}^{2}\right)$ y posee una elevada pendiente $(33.9 \mathrm{~m} / \mathrm{km})$. En cambio, la cuenca del arroyo $G$ abarca $162 \mathrm{~km}^{2}$ y su pendiente es más suave $(5.9 \mathrm{~m} / \mathrm{km})$. El presente estudio se llevó a cabo durante 1 año, relevando datos 
climatológicos (precipitaciones y temperatura) e hidrológicos $(Q$, conductividad eléctrica (CE), temperatura del agua, turbidez y pH). El clima y la topografia de la región establecieron 3 periodos hidrológicos distintivos: Precipitaciones, Deshielo y Basal. El Q presentó un claro régimen estacional. Los mayores caudales se observaron durante el periodo de Deshielo por causa del derretimiento de las nieves en las montañas. El arroyo CP se comportó como un arroyo muy variable en relación con el $Q$, no así el arroyo G. La mayor variabilidad del caudal se observó durante el periodo de Precipitaciones. El periodo Basal se caracterizó por su escaso caudal. La temperatura del agua fluctuó entre los distintos periodos hidrológicos y entre los arroyos de estudio. En cambio, el pH solo fluctuó estacionalmente. La elevada escorrentía durante el periodo de Precipitaciones trajo aparejado el lavado de los suelos y esto a su vez, una mayor turbidez a los arroyos. En el arroyo CP la relación entre el $Q$ y la CE revelaría diferentes flujos del agua hacia el arroyo durante el año; flujos provenientes del deshielo, de la escorrentía y subterráneo. En cambio, en el arroyo G, la EC fue elevada y constante durante todo el periodo de estudio, independientemente del caudal; indicando al gran lago en su cabecera como su principal aporte de agua. Este lago influyó claramente en las dinámicas físico-químicas del arroyo G. Este estudio nos permitió indagar sobre procesos hidrológicos con importancia ecológica en los ecosistemas acuáticos Andino-Patagónicos. A raiz de nuestros resultados y de las tendencias de futuro, creemos que las dinámicas hidrológicas y físico-químicas de estos ecosistemas se verán fuertemente afectadas como consecuencia del cambio climático.

Palabras clave: Patagonia, caudal, conductividad eléctrica, periodos hidrológicos

\section{INTRODUCTION}

Streamflow or discharge $(\mathrm{Q})$ is an essential variable in the functioning of fluvial ecosystems (Ziemer \& Lisle, 1998). These systems are fed by rain, ice melt, snowmelt and groundwater, the relative importance of each of these factors varying over time and space. Moreover, Q varies over time frames ranging from hours and days to seasons and years. The pattern of these variations is referred to as the flow regime of a stream (Poff et al., 1997). Stream discharge and flow regime are directly related to the surface area of the drainage basin it runs through. Thus, the smaller the drainage basin area, the lower $\mathrm{Q}$ and the more frequent and faster the changes in $\mathrm{Q}$ (to be more "flashy" sensu Baker et al., 2004). Moreover, the hydrological dynamics of fluvial ecosystems are directly influenced by the presence of headwater lakes (Gordon et al., 2004). A lake is a water trap, thus hydrography of its effluent stream tends to be stable over time (Fongers et al., 2012). Furthermore, Q and its regime have multiple impacts on the physical and chemical characteristics of a stream (Baker et al., 2004).

The study of the physico-chemical properties of water gives us meaningful information on the characteristics of fluvial ecosystems. For example, electrical conductivity (EC) is generally used as an estimator of Total Dissolved Solids (TDS), and as an indicator of hydrological processes (Moore et al., 2008). Moreover, turbidity presents a strong correlation with total suspended solids (TSS) and Total Phosphorus (TP) (Stubblefield et al., 2007) and can thus serve as a good surrogate for these variables. Water temperature is another key variable determining the metabolism of organisms (Gillooly et al., 2001) and $\mathrm{pH}$ is very important both chemically and biologically. As with Q, these physico-chemical variables have their own characteristics in streams, and are affected by the presence of a headwater lake (Gordon et al., 2004). Considering lakes as traps for sediments and nutrients (Parker et al., 2009), their effluent streams might buffered physico-chemical dynamics.

Fluvial ecosystem dynamics are modulated by climate. In mountain regions the hydrological regime of these ecosystems can be divided into three contrasting periods: stormflow, meltflow and baseflow (Ahearn et al., 2004). The stormflow season runs from the beginning of fall to the end of winter. The snow falling at high altitudes contributes to the formation of a snowpack, which remains frozen until the meltflow period. The latter begins when the temperature rises in spring and ends at the beginning of summer. The baseflow period begins in the summer and ends at the beginning of the fall season. According to the updated world map of the Köppen-Geiger climate classification, Northern Patagonia is characterized by a temperate climate with warm and dry summers (Peel et al., 2007). The regional climate is largely determined by the Andes (Paruelo et al., 
1998), since the north-south distribution of these mountains represents an important barrier for humid air masses coming from the Pacific Ocean. Most of the water in these maritime air masses falls on the Chilean side of the Andes, and the air becomes hotter and drier through adiabatic warming when descending the Argentine side. East of the Andes, the amount of rainfall follows a west-east gradient. From the western slopes to the eastern limit of the area (about $60 \mathrm{~km}$ ), annual precipitation drops from $3500 \mathrm{~mm}$ to $700 \mathrm{~mm}$. Moreover, the precipitation regime presents marked seasonality, occurring during fall and winter (Paruelo et al., 1998). Within the current framework of climate change affecting the region, there are strong indications of significant warming and decreasing precipitation (Masiokas et al., 2008), which should have an effect on the aquatic ecosystems.

Andean rivers and streams have been under study for over 30 years now (Modenutti et al., 1998), and work carried out in the region has revealed the oligotrophic character of these fluvial ecosystems (Pedrozo et al., 1993). Diverse authors have studied anthropic (Miserendino et al., 2016) and natural (Temporetti, 2006; Lallement et al., 2016; Williams Subiza \& Brand, 2018) elements that have affected Andean drainage basins, and consequently, their fluvial ecosystems. Recent research has revealed the dynamics of organic matter (García et al., 2015b; Díaz Villanueva et al., 2016; García et al., 2018). Nevertheless, studies that focus on $\mathrm{Q}$ are scarce (Barros \& Camilloni, 2016), despite the ecological importance of this variable. Andean streams of Northern Patagonia display a discharge highly dependent on the amount of snow, and then by glacier melt. This is due to the mild environmental conditions and low elevation of Northern Patagonian Andes, which limit the effects of glaciers to relatively small ones on the highest peaks and volcanoes along the mountain range (Lliboutry, 1998). Limnological studies are based on Q data measured over a relatively long time interval, and characterise the hydrological regime of Andean-Patagonian streams only in relation to yearly climate seasonality by displaying a bi-modal pattern. That is, Q is high in autumn and spring due to rainfall and snowmelt, respectively, and is low in winter and summer. No information is given on its stability (as flashiness), or details as to how it relates to physico-chemical variables.

Our main hypothesis is that climate is the principal moderator of aquatic ecosystems in the Andean Patagonian region. Thus, as in other mountain regions, we divided the hydrological regime of Andean Patagonian streams into three contrasting periods: stormflow, meltflow and baseflow. Each of these periods should have its own characteristic discharge and physico-chemical dynamics. We selected two streams that have the characteristic sources of the streams in the region: Casa de Piedra (CP) and Gutiérrez (G). CP originates in a small mountain lake, whereas $G$ arises from a large piedmont lake. In a second hypothesis, we predict that the large headwater lake of stream $\mathrm{G}$ induces a buffer effect on the hydrological and physico-chemical dynamics of the stream, and its fluvial dynamics displays greater stability than CP. The first goal of the current research is to describe the hydrological dynamics of these two streams. A second objective is to characterize the temporal dynamics of temperature of water, EC, $\mathrm{pH}$ and turbidity, and their possible relations to the hydrological regime.

\section{MATERIALS AND METHODS}

\section{Area of study}

The research was conducted at the catchments of the streams Casa de Piedra $\left(41^{\circ} 07^{\prime} 30.11^{\prime \prime} \mathrm{S} 71^{\circ}\right.$ $27^{\prime} 13.16^{\prime \prime} \mathrm{O}$ ) and Gutiérrez ( $41^{\circ} 09^{\prime} 36.18^{\prime \prime} \mathrm{S} 71^{\circ}$ 24' 37.19" O), both located in Nahuel Huapi National Park, Patagonia, Argentina (Fig. 1). The yearly average of air temperature is $8.3^{\circ} \mathrm{C}$ and annual precipitation is $940 \mathrm{~mm}$. This region is dominated by a mixture of crystalline igneous, volcanic and plutonic rocks; pyroclastic rocks are of secondary importance, and metamorphic and sedimentary rocks are present in minor quantities (Pedrozo et al., 1993). Glacial drift and alluvial outwash deposits predominate in the valley bottoms. The area was glaciated extensively and repeatedly during the late Pleistocene (Flint \& Fidalgo, 1964). The soils are classified as Andisols, which are characterized by high capacity to stabilize organic matter, to store water and to 


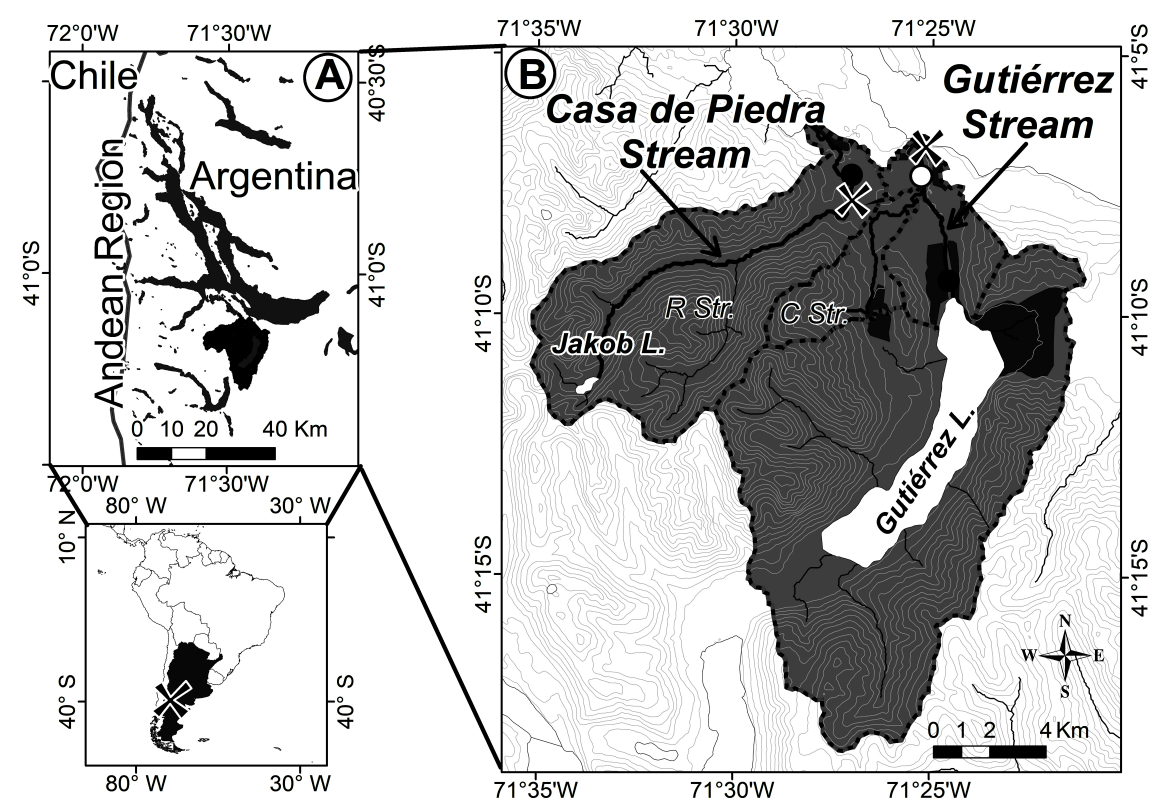

Figure 1. a) Nahuel Huapi National Park; the study area is shaded in black. b) Study area, Catchments of Casa de Piedra and Gutiérrez streams. Curves represent $100 \mathrm{~m}$ slope on the terrain. Populated zones are shown in grey, crosses indicate sampling sites, black circles indicate the Limnigraphic stations and white circle indicate the rain meter location. R Str. and C Str., Rucaco and Cascada streams. a) Parque Nacional Nahuel Huapi, el área de estudio está sombreada en negro. b) Área de estudio, Cuencas de drenaje de los arroyos Casa de Piedra y Gutiérrez. Las curvas representan un desnivel de $100 \mathrm{~m}$. En gris se indican las zonas pobladas, las cruces indican los sitios de muestreo, los círculos negros indican las ubicaciones de los limnígrafos y el círculo blanco indica la ubicación del pluviómetro. R Str. y C Str., arroyos Rucaco y Cascada.

retain phosphorous (Satti et al., 2003). They also have a high $\mathrm{pH}$ buffering capacity. The drainage basins of both streams are very different from each other, despite of their proximity. In the case of $\mathrm{CP}$, the catchment covers $63 \mathrm{~km}^{2}$ and the stream originates in lake Jakob, a deep (25 m maximum depth), small $\left(0.15 \mathrm{~km}^{2}\right)$, ultra-oligotrophic (1-3 $\mu \mathrm{g} / 1 \mathrm{TP})$, high altitude lake, situated at $1550 \mathrm{~m}$ a.s.1. (García et al., 2015a) (Fig. 1). The only affluent is the Rucaco stream having its source in high marshlands. CP flows $19.7 \mathrm{~km}$ through a steep V-shaped valley (slope: 33.9 $\mathrm{m} / \mathrm{km}$ ) from its source until close to its mouth. The CP drainage basin is still pristine, with the major human activity being hiking. The vegetation includes Nothofagus pumilio, and the evergreen tree species Nothofagus dombeyi and Austrocedrus chilensis in the low catchment. In contrast, the catchment of $\mathrm{G}$ is larger $\left(162 \mathrm{~km}^{2}\right)$, and the stream originates in lake Gutiérrez. This lake occupies $11 \%$ of the catchment valley: it is deep (111 m maximum depth) and large $\left(17 \mathrm{~km}^{2}\right)$.
The seasonal concentration of TP is $3.4 \mu \mathrm{g} / 1$ on average (Diaz et al., 2007). G has only one affluent (the Cascada stream) whose drainage basin covers $12.5 \mathrm{~km}^{2}$. G flows $9 \mathrm{~km}$ through a wide, gently sloped valley $(5.9 \mathrm{~m} / \mathrm{km})$. Its riverbanks are extensively colonised by the exotic crack willow, Salix fragilis, and it runs through a series of populated sections of a city (San Carlos de Bariloche). In addition, the products from two salmon farms are emptied into its waters.

\section{Sampling strategy and data collection}

The study was carried out over one year, from 21-3-2014 to 20-3-2015. This period was divided into 3 hydrological periods: stormflow, meltflow and baseflow. The stormflow extended from the beginning of the study up to mid-September (15-9-2014). The meltflow period followed, ending at the beginning of December (5-12-2014), Finally, baseflow occurred from December 6, 2014 to March 20, 2015. The start- 
ing points of the meltflow and baseflow periods were determined by a marked decrease in precipitation in the drainage basin, and the EC dynamics in CP. The dynamics of EC from mountain streams displays a gradual decrease throughout meltflow (Drever \& Zobrist, 1992; Sueker et al., 2000), reaching its lowest level just before the beginning of baseflow (Ahearn, personal communication to the first author). The Provincial Water Department provided the data on precipitations and Q. Daily precipitation records were obtained with a rain meter (Fig. 1) and do not differentiate between rain or snow. Discharge data were average daily records from two limnigraphic stations. These stations were set to estimate the pressure of the water column each 30 minutes and store the information on a hard disk. Every 2 months data were collected, and the corresponding hydrometric gauging was performed. The limnigraphic station for CP is located close to its mouth, while for the stream $G$ is located at its source (Fig. 1). The $Q$ value for $G$ at our sampling site was estimated from the sum of $Q$ at its source plus $Q$ for the Cascada stream. We determined $Q$ for Cascada using the Drainage-Area Ratio method (Emerson et al., 2005), taking the specific daily value of $Q$ for the nearby CP stream. Specific discharge was defined as discharge per unit area. The National Meteorological Service provided average daily air temperatures.

We measured the following stream water variables: turbidity with a Velp turbidimeter, and temperature, EC compensated to $25^{\circ} \mathrm{C}$ and $\mathrm{pH}$ with an Oakton probe. Sampling was conducted twice weekly during the morning hours. This frequency was increased whenever precipitation was forecasted by taking daily samples before, during and after the precipitation event (Casson et al., 2012; Tate \& Singer, 2013). Hence sampling frequency varied between 8 and 15 samples per month.

\section{Data processing and analysis}

\section{Variability of discharge}

The stream flashiness was measured by the Richards-Baker (R-B) index (Baker et al., 2004), whose formula is as follows:

$$
R-B \text { Index }=\frac{\sum_{i=n}^{n}\left|q_{i}-q_{i-1}\right|}{\sum_{i=1}^{n} q_{i}}
$$

The variable $q$ is the mean daily flow whereas $n$ is the number of observations. This index measures oscillations in discharge relative to total discharge. Thus, it is a dimensionless measure ranging between 0 and 2 (Fongers et al., 2012). A value of 0 represents an absolutely constant flow; increased R-B index values indicate increased flashiness of streamflow. As such, the index appears to provide a useful characterization of the way watersheds process hydrological inputs into their streamflow outputs. The index may be calculated annually or seasonally (Baker et al., 2004).

\section{Data treatment}

Data on the average daily Q were transformed to normality by the Box-Cox procedure as suggested by Peltier et al. (1998). The transformed records were then analyzed with a fixed effects two-way linear model with interaction. Main effects were hydrological period (3 levels) and stream (2 levels). PROC MIXED of SAS (SAS Institute Inc., 2013) was employed to account for heterogeneous variances due to stream.

The Cox and Stuart (1955) test was used to analyze trends in Q from the different hydrological periods. This test allows verifying whether a variable displays a monotonical trend. The null hypothesis is that the data shows no trend. The test behaves similarly to the sign test for two independent samples (Daniel, 1978).

In addition, we studied the relationship between discharge and environmental variables during each hydrological period and carried out a cross-correlation analysis. The methodology is widely used to analyze the linear relationship between input and output signals in hydrology (Larocque et al., 1998). In our research, the input signals were the precipitation and air temperature, and the output signal was the river discharge of CP and G. Cross-correlations are represented by a cross-correlogram. The maximum amplitude and the lag value of the cross-correlogram provide information on the delay, which indicates 


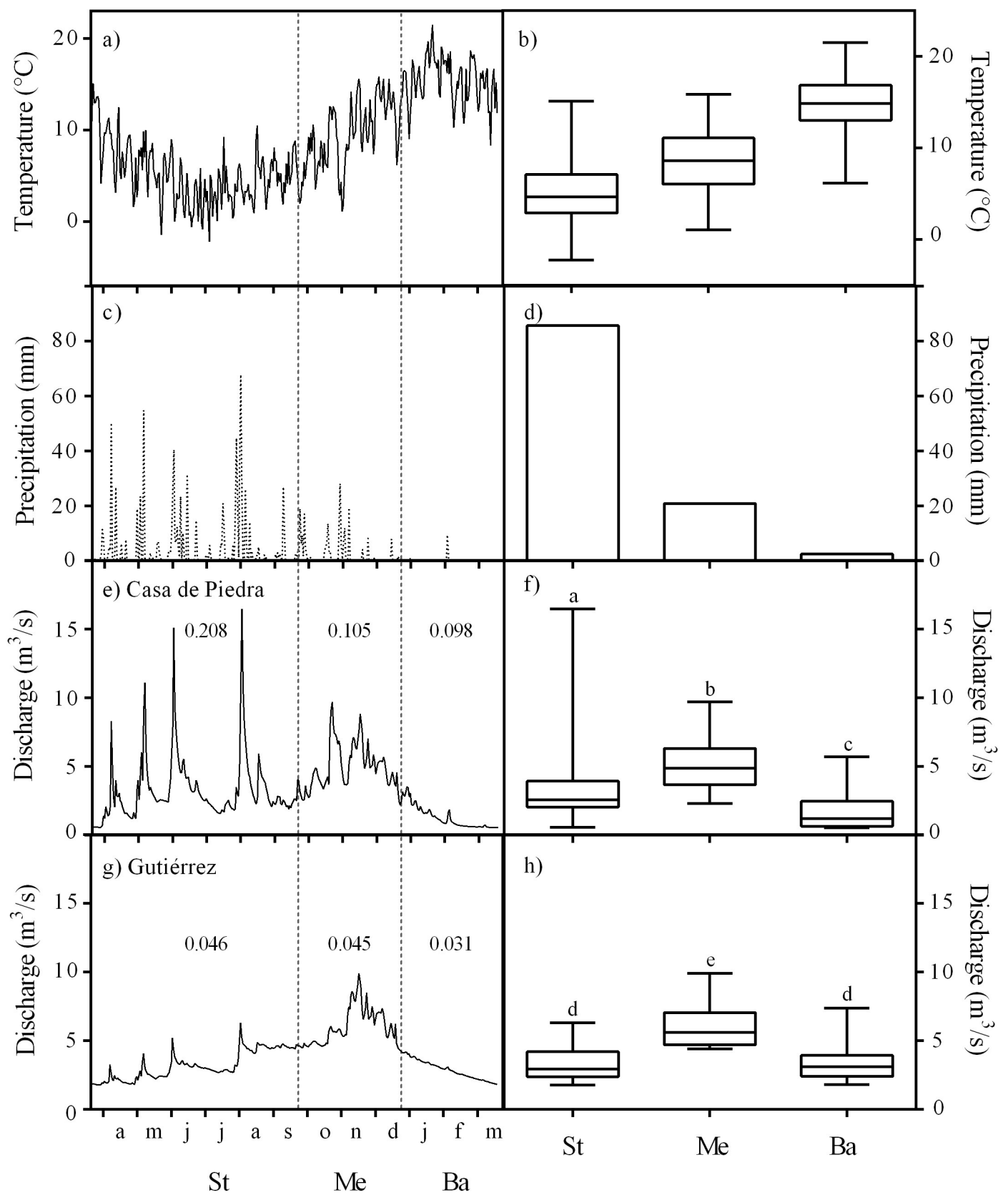

Figure 2. Left panels: a) Temperature, c) Precipitation, e) Casa de Piedra stream hydrograph and g) Gutiérrez stream hydrograph. e) and g) R-B index values are shown on the different hydrological periods. Right panels: box-plot of the same data. Data is divided into 3 hydrological periods, Stormflow $(\mathrm{St})(\mathrm{n}=179)$, Meltflow $(\mathrm{Me})(\mathrm{n}=81)$ and Baseflow $(\mathrm{Ba})(\mathrm{n}=105)$. The boundary of the box closest to zero indicates the $25^{\text {th }}$ percentile, a line within the box marks the median, and the boundary of the box farthest from zero indicates the $75^{\text {th }}$ percentile. Whiskers indicate the range. $\left.\mathrm{f}\right)$ and $\mathrm{h}$ ) Letters (a, b, c, d and e) represent significantly differences $(P<$ 0.05 ) in Discharge from the interaction between streams x periods. Paneles izquierdos: a) Temperatura, c) Precipitaciones, e) Hidrograma del arroyo Casa de Piedra, g) Hidrograma del arroyo Gutiérrez. e) y g) Se muestran los valores de los índices R-B para los diferentes periodos. Paneles derechos: representa el mismo conjunto de datos en diagramas de cajas. Los datos están divididos en los 3 períodos hidrológicos, Precipitaciones $(\mathrm{St})(n=179)$, Deshielo $(\mathrm{Me})(n=81)$ y Basal $(\mathrm{Ba})(n=105)$. El límite del cuadro más cercano a cero indica el percentil 25 , una línea dentro del cuadro marca la mediana y el límite del cuadro más alejado de cero indica el percentil 75. Los bigotes indican el rango. f) y h) Las letras ( $a, b, c, d y$ e) representan diferencias significativas del caudal ( $\mathrm{P}<$ 0.05) de la interacción arroyos x periodos hidrológicos. 
the time of the pulse transfer to the stream. The statistical analysis of discharge included the stream $\mathrm{x}$ period interaction, and the linear covariates temperature and rainfall nested within the interaction. Again, a heterogeneous residual variance was fitted to the model $\mathrm{CP}$ displayed more variability than $\mathrm{G}$.

To quantify the relation between $\mathrm{Q}$ and the physico-chemical variables of the streams, we carried out Spearman correlations. Physico-chemical data was analyzed with the two-factor interaction model with heterogeneous variance as discussed before.

\section{RESULTS}

\section{Climate and hydrology}

Air temperature and precipitation in the study area were typical of the temperate climate in the region. Average annual air temperature was 8.7 ${ }^{\circ} \mathrm{C}$, with the lowest value recorded during stormflow (Fig. 2a). Air temperature increased evenly during meltflow. On average, the highest temperature was recorded during baseflow. Annual precipitation was $1092 \mathrm{~mm}$, with $79 \%$ occurring during the stormflow period (Fig. 2d). The meltflow and baseflow periods accounted for $19 \%$ and $2 \%$ of total precipitation, respectively.

The $\mathrm{Q}$ regime and its associated variables differed annually between the two streams (Fig. 2e, g; Table 1). Annual average $\mathrm{Q}$ was higher for $\mathrm{G}$ $(\mathrm{F}=129 ; P<0.0001 ;$ d.f. $=1)$, although the specific $\mathrm{Q}$ was not $(\mathrm{F}=14928 ; P<0.0001 ;$ d.f. $=1)$. The most extreme values of $\mathrm{Q}$ were observed at $\mathrm{CP}$. These differences highlight the marked temporal fluctuation of Q for CP, whereas G showed greater stability in the values of $Q$. The annual R-B indices were 0.16 for $\mathrm{CP}$ and 0.04 for $\mathrm{G}$, indicating that the average day-to-day fluctuations of streamflow were $16 \%$ and $4 \%$, respectively.

Moreover, the hydrological regime of the streams differed between the stormflow, meltflow and baseflow periods. During stormflow, precipitation was positively correlated to $\mathrm{Q}$ in both streams (Fig. 3a; Table 2a; CP: $\mathrm{t}=7.13 ; P<$ $0.001 ;$ d.f. $=356 ; \mathrm{G}: \mathrm{t}=2.77 ; P=0.0059$; d.f. $=$ 356). The correlation between precipitation and discharge differed between streams and was
Table 1. Hydrological variables of the study streams. Values were obtained from a daily temporal scale $(\mathrm{n}=365)$. Discharge (Q), Specific Discharge (Q sp.). Variables hidrológicas de los arroyos de estudio. Los valores fueron obtenidos a partir de una escala temporal diaria $(n=365)$. Caudal $(Q)$, Caudal específico ( $Q$ sp.).

\begin{tabular}{ccccc}
\hline Stream & $\begin{array}{c}\mathrm{Q} \\
\text { Annual } \\
\text { Average }\end{array}$ & $\begin{array}{c}\mathrm{Q} \\
\max .\end{array}$ & $\begin{array}{c}\mathrm{Q} \\
\mathrm{min} .\end{array}$ & $\begin{array}{c}\text { Q sp. Annual } \\
\text { average }\end{array}$ \\
\hline & & $\mathrm{m}^{3} / \mathrm{s}$ & & $\mathrm{m}^{3} \cdot \mathrm{s}^{-1} \cdot \mathrm{km}^{-2}$ \\
\hline $\begin{array}{c}\text { Casa de } \\
\text { Piedra }\end{array}$ & 3.220 & 16.500 & 0.550 & 0.051 \\
Gutiérrez & 3.855 & 9.920 & 1.787 & 0.024 \\
\hline
\end{tabular}

higher in $\mathrm{CP}(\mathrm{CP} r(\max )=0.35$ versus $\mathrm{Gr}(\max )$ $=0.19$ ). After a rainfall the maximum value of $\mathrm{Q}$ was reached the next day for $\mathrm{CP}$, whereas $\mathrm{Q}$ peaked 3 to 4 days later in $G$ (Fig. 3a). These differences in the relationship between $Q$ and precipitation are well noticed in the hydrograms, where the variability in discharge is considerably higher in CP than in G (Fig. 2e, g). For CP in the latter period discharge did not showed any trend $(P(\mathrm{~K} \leq 34 \mid 82 ; 0.5)=0.1507)$, whereas in $\mathrm{G}$ the discharge evidenced a tendency to increase $(P(\mathrm{~K}$ $\leq 5 \mid 82 ; 0.5)<0.0001)$. Notwithstanding this, the highest value of $\mathrm{Q}$ was observed at other time than stormflow (Fig. 2f, h) even though the period displayed the highest records of precipitation and stream flashiness.

During meltflow the temperature, but not the precipitation, had a positive relationship with $\mathrm{Q}$ for both streams (Fig. 3b; Table 2b; CP; $\mathrm{t}=4.67$; $P<0.001$, d.f. $=356 ; \mathrm{G} ; \mathrm{t}=4.98 ; P<0.001$, d.f. $=356)$. The correlation was sizeable for both streams $(\mathrm{CP} \mathrm{r}(\max )=0.74 ; \mathrm{G} \mathrm{r}(\max )=0.68)$, and the delay times were short (1 day). Comparing the meltflow period with the previous one, stream flashiness was almost the same in $\mathrm{G}$ but of lower intensity in CP (Fig. 2e, g). Also, the largest discharge was observed for both streams during meltflow (Fig. 2f, h).

Contrary to the observations in meltflow and stormflow, neither precipitation nor temperature were positively correlated to discharge during the baseflow period (Fig. 3c; Table 2c). The effects of the scarce precipitations with high tempera- 
Precipitation - Discharge Temperature - Discharge

a) Stormflow
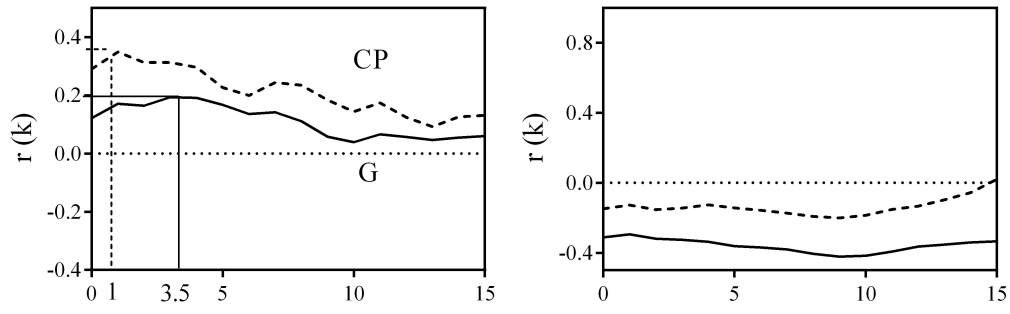

b) Meltflow
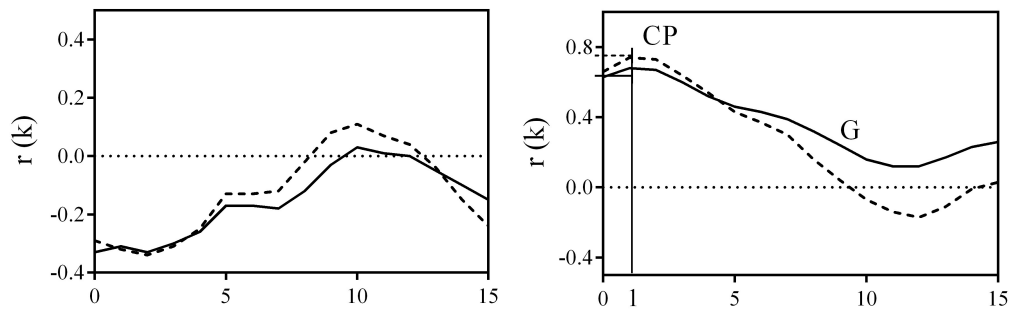

c) Baseflow
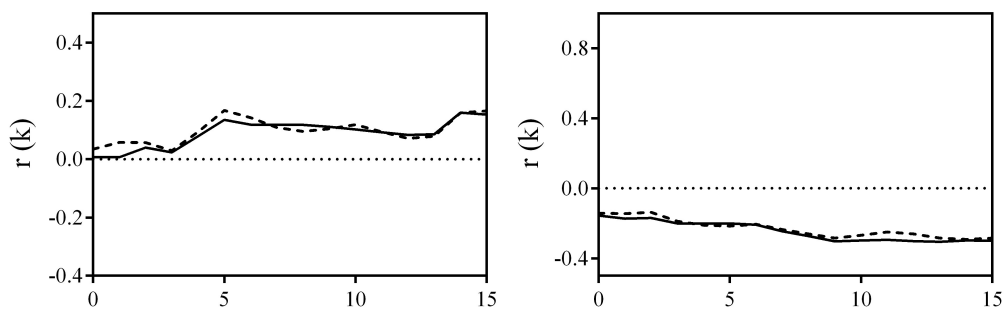

Lag (days)

Figure 3. Cross-correlations between precipitation-discharge (left panels) and air temperature-discharge (right panels) of Casa de Piedra (CP) and Gutiérrez $(\mathrm{G})$ streams in the three hydrological periods. The lags for the maximum $\mathrm{r}$ are given for both streams in the stormflow period (left panel) and in the meltflow period (right panel). Correlaciones cruzadas entre las precipitaciones y el caudal (panel izquierdo) y la temperature del aire y el caudal (panel derecho) de los arroyos Casa de Piedra (CP) y Gutiérrez (G) para los 3 periodos hidrológicos. El período de retraso para los mayores r se muestra para el período de Precipitaciones (panel izquierdo) y para el periodo de Deshielo (panel derecho).

tures during baseflow give raise to a negative relationship between air temperature and discharge in both streams $(\mathrm{CP} ; \mathrm{t}=-2.70 ; P=$ 0.0073 , d.f. $=356 ; \mathrm{G} ; \mathrm{t}=-2.56 ; P=0.0109$, d.f. $=$ 356). The $Q$ values and variabilities for $C P$ and $G$ presented the lowest values from the whole recording time (Fig. 2e-h). For G, the difference in $\mathrm{Q}$ between baseflow and stormflow was not significant (Fig. 2h). Also, it was clearly observed a downward trend in the values of $\mathrm{Q}$ for both streams $(\mathrm{CP}, P(\mathrm{~K} \leq 0 \mid 40 ; 0.5)<0.0001 ; \mathrm{G}, P(\mathrm{~K}$ $\leq 0 \mid 40 ; 0.5)<0.0001)$.

\section{Physico-chemical dynamics}

Air and water temperatures were closely related throughout the observation period (Fig. 2a, 4a). Hence, there were differences in water temperature for both streams among the three hydrological periods (Fig. 4b, c). Only during meltflow water temperatures at $\mathrm{CP}$ and $\mathrm{G}$ were positively correlated with discharge (Fig. 5a, b). In addition, water temperature at $\mathrm{CP}$ was $3{ }^{\circ} \mathrm{C}$ colder than at $\mathrm{G}$ (Table 3).

A different picture emerges when comparing 
Table 2a-c. Level of significance $(P)$ of the cross-correlations analysis (r) between Discharge of the study streams and the climatic variables in the three hydrological periods (lag from 0 to 15 days). a) Stormflow, b) Meltflow and c) Baseflow. Casa de Piedra (CP); Gutiérrez (G). Nivel de significancia (P) de las correlaciones cruzadas (r) entre el Caudal de los arroyos de estudio y las variables climatológicas en los tres periodos hidrológicos (retraso de 0 a 15 días). a) Precipitaciones, b) Deshielo y c) Basal. Casa de Piedra $(C P)$; Gutiérrez (G).

a) Stormflow period

\begin{tabular}{|c|c|c|c|c|c|c|c|c|c|}
\hline \multirow{2}{*}{$\begin{array}{c}\mathrm{Lag} \\
\text { (days) }\end{array}$} & \multicolumn{4}{|c|}{ Discharge-Precipitacion } & \multirow{2}{*}{$\begin{array}{c}\mathrm{Lag} \\
\text { (days) }\end{array}$} & \multicolumn{4}{|c|}{ Discharge-Temperature } \\
\hline & $\mathrm{r}_{\mathrm{CP}}$ & $P_{\mathrm{CP}}$ & $\mathrm{r}_{\mathrm{G}}$ & $P_{\mathrm{G}}$ & & $\mathrm{r}_{\mathrm{CP}}$ & $P_{\mathrm{CP}}$ & $\mathrm{r}$ & $P_{\mathrm{G}}$ \\
\hline 0 & 0.29 & 0.0001 & 0.12 & 0.1056 & 0 & -0.15 & 0.0477 & -0.31 & 0.0000 \\
\hline 1 & 0.35 & 0.0000 & 0.17 & 0.0222 & 1 & -0.13 & 0.0911 & -0.29 & 0.0001 \\
\hline 2 & 0.31 & 0.0000 & 0.16 & 0.0288 & 2 & -0.15 & 0.0418 & -0.32 & 0.0000 \\
\hline 3 & 0.31 & 0.0000 & 0.19 & 0.0102 & 3 & -0.14 & 0.0563 & -0.33 & 0.0000 \\
\hline 4 & 0.30 & 0.0001 & 0.19 & 0.0113 & 4 & -0.13 & 0.0987 & -0.34 & 0.0000 \\
\hline 5 & 0.23 & 0.0027 & 0.17 & 0.0274 & 5 & -0.14 & 0.0588 & -0.36 & 0.0000 \\
\hline 6 & 0.20 & 0.0085 & 0.14 & 0.0742 & 6 & -0.16 & 0.0389 & -0.37 & 0.0000 \\
\hline 7 & 0.24 & 0.0013 & 0.14 & 0.0636 & 7 & -0.17 & 0.0230 & -0.38 & 0.0000 \\
\hline 8 & 0.23 & 0.0020 & 0.11 & 0.1489 & 8 & -0.19 & 0.0118 & -0.41 & 0.0000 \\
\hline 9 & 0.18 & 0.0163 & 0.06 & 0.4541 & 9 & -0.20 & 0.0085 & -0.42 & 0.0000 \\
\hline 10 & 0.14 & 0.0620 & 0.04 & 0.6151 & 10 & -0.19 & 0.0155 & -0.42 & 0.0000 \\
\hline 11 & 0.17 & 0.0243 & 0.07 & 0.3963 & 11 & -0.15 & 0.0488 & -0.39 & 0.0000 \\
\hline 12 & 0.12 & 0.1096 & 0.06 & 0.4640 & 12 & -0.13 & 0.0868 & -0.36 & 0.0000 \\
\hline 13 & 0.09 & 0.2360 & 0.05 & 0.5505 & 13 & -0.10 & 0.2147 & -0.35 & 0.0000 \\
\hline 14 & 0.13 & 0.1063 & 0.05 & 0.4864 & 14 & -0.06 & 0.4828 & -0.34 & 0.0000 \\
\hline 15 & 0.13 & 0.0930 & 0.06 & 0.4452 & 15 & 0.02 & 0.7873 & -0.33 & 0.0000 \\
\hline
\end{tabular}

b) Meltflow period

\begin{tabular}{|c|c|c|c|c|c|c|c|c|c|}
\hline \multirow{2}{*}{$\begin{array}{c}\text { Lag } \\
\text { (days) }\end{array}$} & \multicolumn{4}{|c|}{ Discharge-Precipitacion } & \multirow{2}{*}{$\begin{array}{c}\text { Lag } \\
\text { (days) }\end{array}$} & \multicolumn{4}{|c|}{ Discharge-Temperature } \\
\hline & $\mathrm{r}_{\mathrm{CP}}$ & $P_{\mathrm{CP}}$ & $\mathrm{r}_{\mathrm{G}}$ & $P_{\mathrm{G}}$ & & $\mathrm{r}_{\mathrm{CP}}$ & $P_{\mathrm{CP}}$ & $\mathrm{r}_{\mathrm{G}}$ & $P_{\mathrm{G}}$ \\
\hline 0 & -0.29 & 0.0095 & -0.33 & 0.0029 & 0 & 0.66 & 0.0000 & 0.63 & 0.0000 \\
\hline 1 & -0.32 & 0.0044 & -0.31 & 0.0057 & 1 & 0.74 & 0.0000 & 0.68 & 0.0000 \\
\hline 2 & -0.34 & 0.0024 & -0.33 & 0.0033 & 2 & 0.73 & 0.0000 & 0.67 & 0.0000 \\
\hline 3 & -0.31 & 0.0063 & -0.30 & 0.0076 & 3 & 0.64 & 0.0000 & 0.60 & 0.0000 \\
\hline 4 & -0.25 & 0.0315 & -0.26 & 0.0223 & 4 & 0.54 & 0.0000 & 0.52 & 0.0000 \\
\hline 5 & -0.13 & 0.2689 & -0.17 & 0.1424 & 5 & 0.43 & 0.0001 & 0.46 & 0.0000 \\
\hline 6 & -0.13 & 0.2517 & -0.17 & 0.1416 & 6 & 0.37 & 0.0011 & 0.43 & 0.0001 \\
\hline 7 & -0.12 & 0.2949 & -0.18 & 0.1287 & 7 & 0.30 & 0.0101 & 0.39 & 0.0005 \\
\hline 8 & -0.02 & 0.8867 & -0.12 & 0.3326 & 8 & 0.16 & 0.1809 & 0.32 & 0.0063 \\
\hline 9 & 0.08 & 0.5150 & -0.03 & 0.8149 & 9 & 0.04 & 0.7549 & 0.24 & 0.0455 \\
\hline 10 & 0.11 & 0.3452 & 0.03 & 0.8131 & 10 & -0.07 & 0.5687 & 0.16 & 0.1878 \\
\hline 11 & 0.07 & 0.5736 & 0.01 & 0.9126 & 11 & -0.14 & 0.2610 & 0.12 & 0.3244 \\
\hline 12 & 0.04 & 0.7363 & 0.00 & 0.9929 & 12 & -0.17 & 0.1634 & 0.12 & 0.3201 \\
\hline 13 & -0.04 & 0.7355 & -0.05 & 0.6730 & 13 & -0.11 & 0.3718 & 0.17 & 0.1782 \\
\hline 14 & -0.15 & 0.2407 & -0.10 & 0.4037 & 14 & -0.01 & 0.9247 & 0.23 & 0.0669 \\
\hline 15 & -0.24 & 0.0570 & -0.15 & 0.2414 & 15 & 0.03 & 0.8134 & 0.26 & 0.0352 \\
\hline
\end{tabular}

c) Baseflow period

\begin{tabular}{|c|c|c|c|c|c|c|c|c|c|}
\hline \multirow{2}{*}{$\begin{array}{c}\mathrm{Lag} \\
\text { (days) }\end{array}$} & \multicolumn{4}{|c|}{ Discharge-Precipitacion } & \multirow{2}{*}{$\begin{array}{c}\text { Lag } \\
\text { (days) }\end{array}$} & \multicolumn{4}{|c|}{ Discharge-Temperature } \\
\hline & $r_{C P}$ & $P_{\mathrm{CP}}$ & $r_{G}$ & $P_{\mathrm{G}}$ & & $r_{C P}$ & $P_{\mathrm{CP}}$ & $\mathrm{r}_{\mathrm{G}}$ & $P_{\mathrm{G}}$ \\
\hline 0 & 0.03 & 0.7237 & 0.01 & 0.9422 & 0 & -0.14 & 0.1492 & -0.15 & 0.1152 \\
\hline 1 & 0.06 & 0.5591 & 0.01 & 0.9437 & 1 & -0.14 & 0.1461 & -0.17 & 0.0793 \\
\hline 2 & 0.06 & 0.5681 & 0.04 & 0.6918 & 2 & -0.14 & 0.1662 & -0.17 & 0.0875 \\
\hline 3 & 0.03 & 0.7753 & 0.02 & 0.8193 & 3 & -0.19 & 0.0583 & -0.20 & 0.0428 \\
\hline 4 & 0.09 & 0.3523 & 0.08 & 0.4328 & 4 & -0.21 & 0.0339 & -0.20 & 0.0429 \\
\hline 5 & 0.17 & 0.0977 & 0.14 & 0.1794 & 5 & -0.21 & 0.0318 & -0.20 & 0.0450 \\
\hline 6 & 0.14 & 0.1590 & 0.12 & 0.2396 & 6 & -0.21 & 0.0409 & -0.21 & 0.0384 \\
\hline 7 & 0.11 & 0.2836 & 0.12 & 0.2450 & 7 & -0.24 & 0.0198 & -0.25 & 0.0145 \\
\hline 8 & 0.09 & 0.3557 & 0.12 & 0.2484 & 8 & -0.26 & 0.0097 & -0.27 & 0.0068 \\
\hline 9 & 0.10 & 0.3115 & 0.11 & 0.2829 & 9 & -0.28 & 0.0049 & -0.30 & 0.0027 \\
\hline 10 & 0.12 & 0.2490 & 0.10 & 0.3235 & 10 & -0.27 & 0.0086 & -0.30 & 0.0034 \\
\hline 11 & 0.09 & 0.3677 & 0.09 & 0.3793 & 11 & -0.25 & 0.0149 & -0.30 & 0.0039 \\
\hline 12 & 0.07 & 0.4997 & 0.08 & 0.4314 & 12 & -0.26 & 0.0116 & -0.30 & 0.0033 \\
\hline 13 & 0.08 & 0.4543 & 0.09 & 0.4142 & 13 & -0.28 & 0.0061 & -0.31 & 0.0031 \\
\hline 14 & 0.16 & 0.1317 & 0.16 & 0.1296 & 14 & -0.29 & 0.0050 & -0.30 & 0.0041 \\
\hline 15 & 0.17 & 0.1174 & 0.15 & 0.1503 & 15 & -0.29 & 0.0064 & -0.30 & 0.0042 \\
\hline
\end{tabular}


Table 3. ANOVA results from the comparison of the physico-chemical variables between the study streams. Average values, maximum and minimum in brackets $(\mathrm{n}=113$, except $\mathrm{pH}$ data values $\mathrm{n}=100)$. Resultados de los ANOVA de las comparaciones de las variables físico-químicas entre los arroyos de estudio. Valores promedio, máximos y mínimos entre paréntesis $(n=113$ excepto para los datos de $\mathrm{pH} n=100$ ).

\begin{tabular}{cccccc}
\hline & $\begin{array}{c}\text { Casa de } \\
\text { Piedra }\end{array}$ & Gutiérrez & df & F-value & $P$-value \\
\hline Temperature $\left({ }^{\circ} \mathrm{C}\right)$ & $6.3(1.3-16.3)$ & $9.5(5.7-16.8)$ & 1 & 145.72 & $<0.0001$ \\
\hline $\begin{array}{c}\text { Electrical } \\
\text { Conductivity }(\mu \mathrm{s} / \mathrm{cm})\end{array}$ & $42(22-65)$ & $74(69-80)$ & 1 & 995.76 & $<0.0001$ \\
\hline $\mathrm{pH}$ & $7.3(6.3-8.1)$ & $7.3(6.4-7.8)$ & 1 & 0.35 & 0.5574 \\
\hline Turbidity $(\mathrm{NTU})$ & $0.8(0-20.4)$ & $2.4(0-48.0)$ & 1 & 6.48 & 0.0116 \\
\hline
\end{tabular}

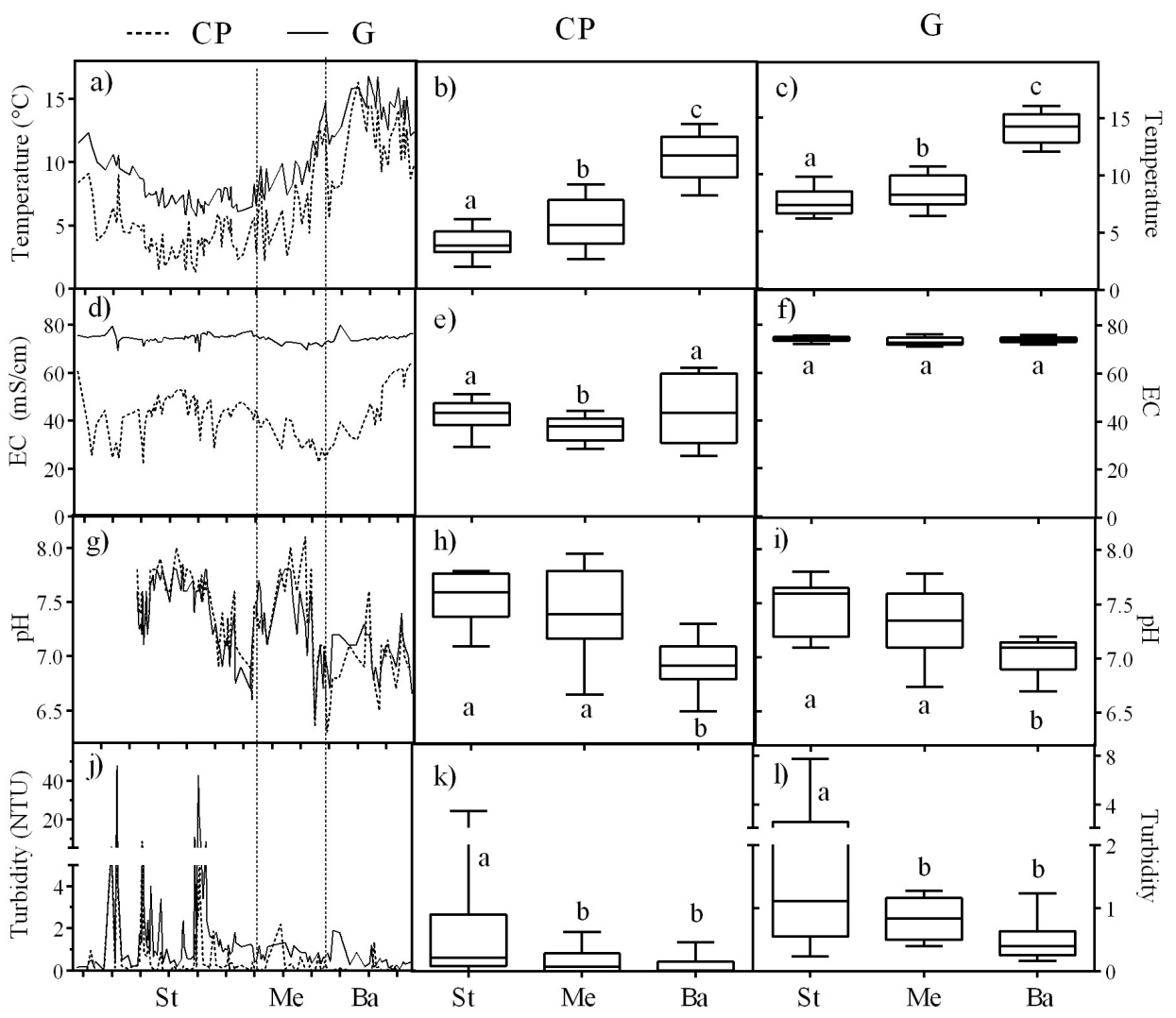

Figure 4. Left panel: Temporal variation of the physico-chemical variables in Casa de Piedra (CP) and Gutiérrez (G) streams. Middle and right panels: box-plots of the same data. The boundary of the box closest to zero indicates the $25^{\text {th }}$ percentile, the line within the box marks the median, and the boundary of the box farthest from zero indicates the $75^{\text {th }}$ percentile. Whiskers indicate the $10^{\text {th }}$ and $90^{\text {th }}$ percentiles. For a given stream, box-plots with the same letter (a, b or c) are not significantly different (ANOVA, $\left.P<0.05\right)$. EC: Electrical conductivity, St: Stormflow, Me: Meltflow and Ba: Baseflow. The Y axis in graphs j), k) and 1) has 2 segments for better visualisation of the data. Panel izquierdo: Variación temporal de las variables físico-químicas en los arroyos Casa de Piedra (CP) y Gutiérrez $(G)$. Los paneles del centro y derechos representan el mismo conjunto de datos en diagramas de caja. El límite de la casilla más cercana a cero indica el percentil 25 , una línea dentro del cuadro marca la mediana y el límite del cuadro más alejado de cero indica el percentil 75. Los bigotes indican el percentil 10 y 90. Para cada arroyo, los diagramas de caja con la misma letra (a, b o c) no son significativamente diferente entre sí (ANOVA, P < 0.05). EC: Conductividad eléctrica, St: Precipitaciones, Me: Deshielo y Ba: Basal. El eje Y posee 2 segmentos para una mejor visualización de los datos en los gráficos j) k) y l). 
the electric conductivities of both streams. The EC of CP was significantly less than the one from $\mathrm{G}$ (Table 3). At CP, EC was relatively high during stormflow and baseflow, with the lowest observed values during meltflow (Fig. 4e). A sharp decrease in $\mathrm{EC}$ was observed during rainy days of the stormflow period. Whereas during meltflow EC tended to decrease over time, the

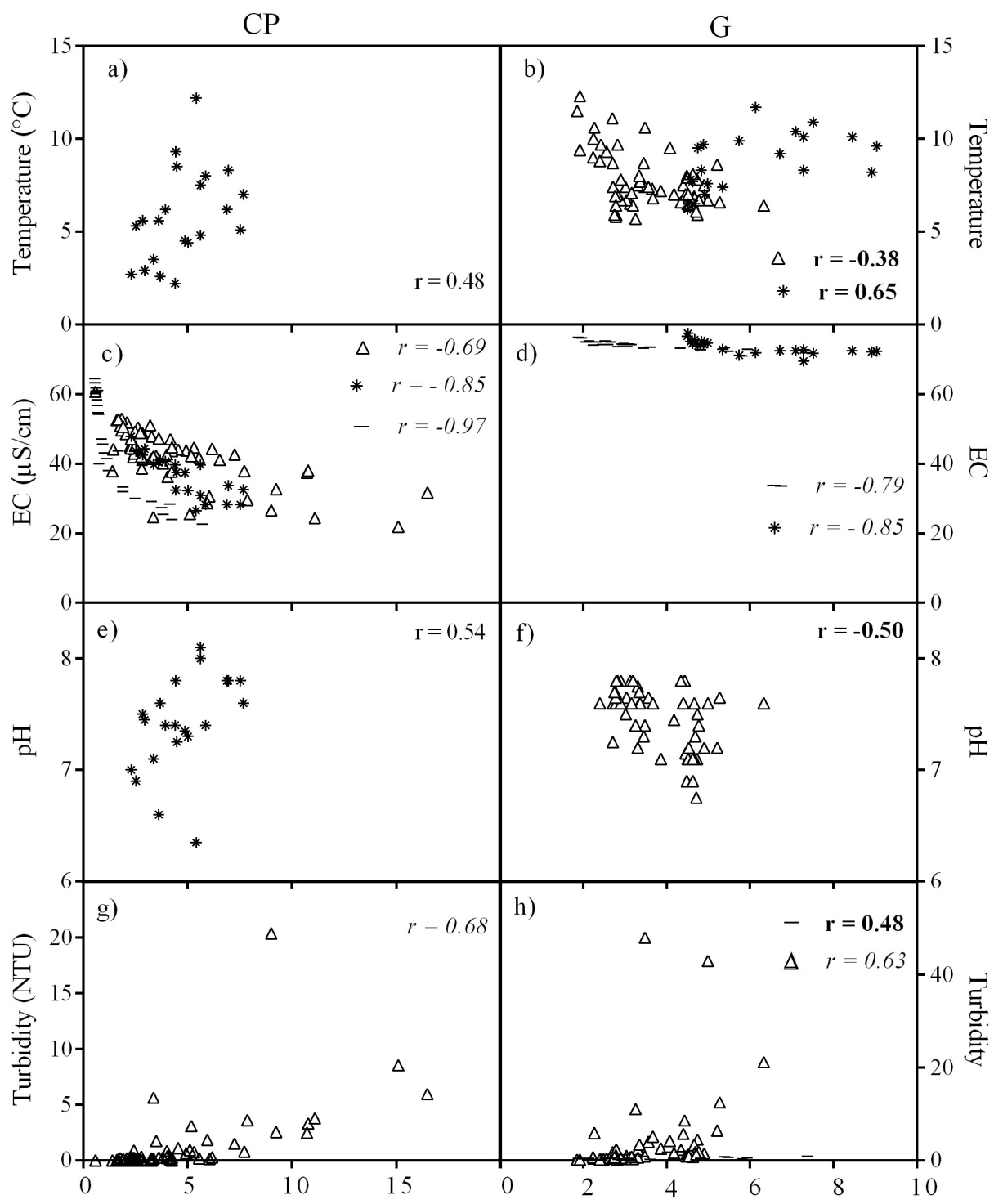

Discharge $\left(\mathrm{m}^{3} / \mathrm{s}\right)$

Figure 5. Spearman correlation between discharge and physico-chemical variables in the different hydrological periods. Stormflow: $\Delta$, Meltflow: * and Baseflow: -. Only correlations with $P \leq 0.05$ are shown. Values in bold are statistically significant at $P \leq 0.01$; those in italics are statistically significant at $P \leq 0.0001$. EC: Electrical Conductivity. Panels g) and h) have different scales in their Y axes. Note the difference between axes $\mathrm{X}$ for each stream. Correlación de Spearman entre el caudal de los arroyos y las variables fisico-químicas en los diferentes periodos hidrológicos. Precipitaciones: $\Delta$, Deshielo: * y Basal: -. Se muestran solamente las correlaciones con $\mathrm{P} \leq 0.05$. Los valores en negrita son estadisticamente significativos a $\mathrm{P} \leq 0.01$, aquellos en itálicas son estadísticamente significativos a $\mathrm{P} \leq 0.0001$. EC: Conductividad eléctrica. Los gráficos g) y h) poseen diferentes escalas en sus ejes $Y$. Notar la diferencia en los ejes X de ambos arroyos. 
trend was reversed during the next period (Fig. 4d). High values of $Q$ corresponded to low EC values in the EC-Q relationship in $C P$, and we were able to distinguish three concave up curves associated with each hydrological period (Fig. $5 c)$. In contrast, conductivity remained high and constant in $\mathrm{G}$ during all recording time (Fig. 4d) though no significant differences were found among hydrological periods (Fig. 4f).

Neutral $\mathrm{pH}$ values were observed (some being slightly alkaline) with no significant differences between streams (Table 3). Conversely, there were significant differences for $\mathrm{pH}$ among hydrological periods. The $\mathrm{pH}$ was alkaline during stormflow, and the values decreased during recording time being neutral at the end of observation at baseflow. We detected significant differences in $\mathrm{pH}$ between baseflow and the other two periods (Fig. 4h, i).

Highest values in average and variability of water turbidity were recorded during stormflow (Fig. 4k, 1). Moreover, we observed high values of water turbidity that were in agreement with discharge (Fig. $5 \mathrm{~g}, \mathrm{~h}$ ). The value of water turbidity decreased during meltflow and reached a minimum during baseflow (Fig. 4k, 1). We observed low values of water turbidity during meltflow and baseflow, generally below 1 NTU. Turbidity was significantly low at CP (Table 2).

\section{DISCUSSION AND CONCLUSIONS}

We recorded discharge and physico-chemical dynamics in the Northern Patagonia Andean streams $\mathrm{CP}$ and $\mathrm{G}$ during a year under normal climate conditions. The lowest $\mathrm{Q}$ was observed during the baseflow period, whereas intermediate values of $\mathrm{Q}$ occurred during stormflow to rise to the highest observed $Q$ during meltflow. The increase in $\mathrm{Q}$ was associated to precipitation in the catchment area during stormflow, and to air temperature during meltflow. Moreover, we highlighted the principal differences in the physico-chemical characteristics of both streams. Maximum values of turbidity, conductivity and water temperature were observed in G. We have also found a clear-cut difference in EC dynamics between the two streams, with those values obtained at CP fluctuating markedly, while the ones recorded at $\mathrm{G}$ remaining relatively constant. It was clear that the differences in physico-chemical dynamics were associated with the morphologies at catchment.

The streams CP and G fit in Haines' et al. (1988) classification of river regimes within Group 14, which are characterized by a peak during early to middle spring. The highest $\mathrm{Q}$ in both streams occurred during meltflow, a fact that concurs with the positive correlation between air temperature and $\mathrm{Q}$, thus highlighting that melting snow is the principal source of water for these streams. Intermediate $Q$ values were found during stormflow, being more evident in CP due to the high positive relationship observed between precipitation in the catchment and the values of $Q$. In contrast, the lake acted as a water trap in the catchment of G. Thus, the lake stored much of the rainwater during stormflow to release them later on during the following periods. The marked seasonality of $\mathrm{Q}$, with the highest values during the snowmelt season, was also observed in other mountains regions (Likens et al., 1967; Brown et al., 2003).

Flashiness represents the response of the stream to many factors in the watershed. The R-B indices were 0.16 and 0.04 for $\mathrm{CP}$ and $\mathrm{G}$, respectively. The greater stability of the regime in $\mathrm{Q}$ for $\mathrm{G}$ can be explained by the flow regulation (Baker et al., 2004) induced by the large headwater lake. Moreover, the difference in catchment size between $\mathrm{CP}$ and $\mathrm{G}$ also explained the differences in R-B indices. Small catchments are characterized by steep slopes and high stream density. As a consequence, small catchments have flashier streams than large catchments (Baker et al., 2004). Additionally, the catchments of CP and G present rocky soils or bare grounds from $1500 \mathrm{~m}$ a.s.l. In case of $\mathrm{CP}$, the percentage of bare ground represents $30 \%$ of the total catchment area (Queimaliños et al., 2012). All these characteristics favour superficial or sub-superficial run-off during storm events, thus increasing the R-B index. This index at $\mathrm{CP}$ was similar to values from Alpine streams. Holko et al. (2011) studied the flashiness of Austrian and Slovak streams and found average values of 0.18 and 0.15 , respectively. These authors conclude that the main variables affecting the RB-index are the geology and the size of water- 
shed. Conversely, Fongers et al. (2012) suggested that the main factors influencing R-B index were the size and the use of the watershed.

The dynamics of the variable EC is an indication of water flowpaths to a fluvial ecosystem (Moore et al., 2008). In stream CP we observed three different EC-Q curves; one for each hydrological period. At the same time during stormflow Q peaked while EC dropped to a minimum. Thus, there was a high run-off as a large amount of water runs fast into the stream with little interaction with the land ecosystem. In the Melt season, we observed Q at the highest and EC at the lowest, which indicates that water in the river largely results from melting snow in the uplands and is depleted of TDS (Ahearn et al., 2004). The downward shift of the EC-Q curve over time reflects the progressively upward shift of run-off source areas associated with the rising snow line. This increase in elevation of the source areas for snowmelt run-off would be expected to progressively decrease the EC of water reaching the stream channel, since the rates of rock weathering decrease at higher elevations (Drever \& Zobrist, 1992) and water would flow through thinner, less mature soils (Sueker et al., 2000). Both factors generate more dilute soil water and hence a more diluted streamflow. Finally, in baseflow the lowest Q and the highest $\mathrm{EC}$ were observed. The main source of water for $\mathrm{CP}$ would be groundwater, and the high EC would reflect a larger proportion of dissolved substances due to the longer time of interaction between the water and solutes in the water table. The EC-Q relationships were much less pronounced in $\mathrm{G}$ where the $\mathrm{EC}$ range was highly limited during the entire study period, which translates into a predominant flow path of water towards this stream, lake Gutiérrez. Therefore, the physico-chemical dynamics of $\mathrm{G}$ will be largely determined by the physico-chemical dynamics of its headwater lake. As an example, lakes export heat through their effluents (Toja Santillana, 2005), which coincides with the higher temperatures observed in $\mathrm{G}$ when compared with $\mathrm{CP}$.

The $\mathrm{pH}$ varied seasonally in such a way that both streams present displayed alkaline $\mathrm{pH}$ values during stormflow and neutral values during baseflow. Rain and snow are slightly acid in the region with average $\mathrm{pH}=5.1$ (Pedrozo et al.,
1993). The soils in the catchments of both streams have a pH of around 6 (Satti et al., 2007), a level at which retain $\mathrm{H}^{+}$. Therefore, our results suggest that during stormflow rainwater reaching the streams as superficial or sub-superficial run-offs will be slightly alkalized by the soil, whereas the $\mathrm{pH}$ decreases during the following meltflow. This observation is in line with the naturally acidic characteristics of snow; the decrease in $\mathrm{pH}$ of streams and lakes during snowmelt is a known process which has been studied in other mountain regions (Jeffries et al., 1979; Galloway et al., 1987). During baseflow, the $\mathrm{pH}$ of the stream water was neutral. We did not carry out any studies on the groundwater in the current research, and therefore have no information as to its properties during the recording period. However, measurements taken in the water from a spring close to the streams had $\mathrm{pH}$ close to 6 and EC near the level of $100 \mu \mathrm{S} / \mathrm{cm}$ (personal observations of the first author). Hence, the observed values of $\mathrm{pH}$ and $\mathrm{EC}$ would be consistent with a greater contribution of groundwater to the streams during baseflow. By interpreting the results as a function of the hydrological cycle, we were able to obtain a first approximation of the $\mathrm{pH}$ and EC dynamics on Andean Patagonian streams at catchment scale.

Turbidity varied between hydrological periods (Ahearn et al., 2004), with a tendency of the peak to occur during periods of greater run-off, when the connection between terrestrial and aquatic ecosystems is enhanced. We observed a marked increase in turbidity and $\mathrm{Q}$ on rainy days in agreement with observations of other streams nearby (García et al., 2015). The high turbidity in the streams indicates high levels of TSS (Welch et al., 1998; Moore et al., 2008; Williamson \& Crawford, 2011), and consequently, of nutrients and sediment (Stubblefield et al., 2007). It is therefore possible to hypothesise that the period of highest nutrient and sediment export in the study streams occurs during the stormflow period, an event that has already been observed in Andean Patagonian streams (García et al., 2015b).

This work presents some points which are worthy of clarification and further study. Since the current research was carried out over a one-year period, we were not able to asses inter- 
annual variation of these ecosystems. Furthermore, we did not evaluate the glacier-fed streams, which are also characteristic of the Patagonian Andes (Masiokas et al., 2008; Miserendino et al., 2018). Despite this, the present study offers new insights into Patagonian ecosystem dynamics and allows some past and future scenarios to be explained or predicted.

The variation of climate in Northern Patagonia would be reflected in its fluvial ecosystems. In the recent past, the snow/precipitation ratio was higher than at present times (Barros \& Camilloni, 2016), and so the flashiness observed during stormflow would have been less intensive, and the amount of discharge during meltflow would have been higher than today. Regional simulations of climate change predict a winter temperature increase of about $2{ }^{\circ} \mathrm{C}$ in Patagonia during the late twenty-first century (Nuñez et al., 2008), which will lead to a continued decrease in the snow/total precipitation ratio. We could therefore hypothesise an increase in discharge during stormflow and a decrease during meltflow. If this takes place, the highest flashiness and amount of discharge would occur during the same hydrological period, thus increasing the level of connection between terrestrial and aquatic ecosystems. This would increase the export of substances from the catchment area to the lotic and lentic ecosystems of the region. In addition to the increase in temperature, future scenarios also predict a decrease in precipitation intensity (Masiokas et al., 2008). This would be reflected in an increase in intermittent streams during baseflow in the Andean Patagonian region.

Worldwide, few relatively pristine ecosystems of rivers remain. However, many Andean Patagonian streams can still be found in this unspoiled condition. $\mathrm{CP}$ is an example of a pristine stream and its water is drunk by hikers without any previous treatment. The study of CP and $\mathrm{G}$ gave us insight into hydrological processes of ecological significance, for which there is almost no research in this region. In addition, these processes are difficult to observe in other places that have been extensively modified by man. We have determined that the streams in the region have their greatest discharge during the snowmelt, their highest variability and connec- tion with the terrestrial ecosystem during stormflow while displaying opposing characteristics in baseflow. Furthermore, each of these periods presents particularities into their physico-chemical dynamics. Conservation of these pristine ecosystems, greatly dependent on climatic factors and the characteristics of their catchments, is a commitment that should be undertaken now for the benefit of future generations.

\section{ACKNOWLEDGEMENTS}

We are grateful to the Departamento Provincial de Aguas and the Servicio Meteorológico Nacional for providing hydrological and meteorological data, A. Urquhart for the original English translation, D.S. Ahearn for his interesting comments during the data analysis and writing periods and P. Temporetti and two anonymous reviewers who helped to improve the manuscript. This study was funded by Agencia Nacional de Promoción Cientifica y Tecnológica (PICT 2959). Sosnovsky, A, Cantet, R.J.C, Rechenq, M. and Fernandez, M.V. are CONICET researchers.

\section{REFERENCES}

AHEARN, D. S., R. W. SHEIBLEY, R. A. DAHLGREN \& K. E. KELLER. 2004. Temporal dynamics of stream water chemistry in the last free-flowing river draining the western Sierra Nevada, California. Journal of Hydrology, 295: 47-63. DOI: 10.1016/j.jhydrol.2004. 02.016

BAKER, D. B., R. P. RICHARDS, T. T. LOFTUS \& J. W. KRAMER. 2004. A new flashiness index: Characteristics and applications to midwestern rivers and streams. Journal of the American Water Resources Association, 40 (2): 503-522.

BARROS, V. \& I. CAMILLONI. 2016. La Argentina y el cambio climático De la física a la política. EUDEBA. Ciudad Autónoma de Buenos Aires.

BROWN, L. E., D. M. HANNAH \& A. M. MILNER. 2003. Alpine Stream Habitat Classification: An Alternative Approach Incorporating the Role of Dynamic Water Source Contributions. Artic, Antartic, and Alpine 
Research, 35 (3): 313-322.

CASSON, N. J., M. C. EIMERS \& S. A. WATMOUGH. 2012. Impact of winter warming on the timing of nutrient export from forested catchments. Hydrological Processes, 26: 2546-2554. DOI: 10.1002/hyp.8461

COX, D. R. \& A. STUART. 1955. Some quick tests for trend in location and dispersion. Biometrika, 42: 80-95.

DANIEL, W. W. 1978. Applied Nonparametric Statistics. Houghton Mifflin Company. Boston. Non DOI available.

DIAZ, M. M., F. L. PEDROZO, C. S. REYNOLDS \& P. F. TEMPORETTI. 2007. Chemical composition and the nitrogen-regulated trophic state of Patagonian lakes. Limnologica, 37: 17-27. DOI: 10.1016/j.limno.2006. 08.006

DÍAZ VILLANUEVA, V., M. BASTIDAS NAVARRO \& R. ALABARIÑO. 2016. Seasonal patterns of organic matter stoichiometry along a mountain catchment. Hydrobiologia. DOI: 10.1007/s10750-015-2636-Z

DREVER, J. I. \& J. ZOBRIST. 1992. Chemical weathering of silicate rocks as a function of elevation in the southern Swiss Alps. Geochimica et Cosmochimica Acta, 56: 3209-3216.

EMERSON, D. G., A. V. VECCHIA \& A. L. DAHL. 2005. Evaluation of Drainage-Area Ratio Method Used to Estimate Streamflow for the Red River of the North Basin, North Dakota and Minnesota. U.S. Geological Survey. Reston, Virginia.

FLINT, R. F. \& F. FIDALGO. 1964. Glacial geology of the East Flank of the Argentine Andes between latitude $39^{\circ} 10^{\prime} \mathrm{S}$ and latitude $41^{\circ} 20^{\prime}$ S. Geological Society of America Bulletin, 75: 335-352.

FONGERS, D., R. DAY \& J. RATHBUN. 2012. Application of the Richards-Baker Flashiness Index to gaged Michigan rivers and Streams. Water Resources Division, Michigan Department of Environmental Quality. Lansing.

GALLOWAY, J. N., G. R. HENDREY, C. L. SCHOFIELD, N. E. PETERS \& A. H. JOHANNES. 1987. Processes and Causes of Lake Acidification during Spring Snowmelt in the West-Central Adirondack Mountains,
New York. Canadian Journal of Fisheries and Aquatic Sciences, 44: 1595-1602.

GARCÍA, D. R., M. C. DIÉGUEZ, M. GEREA \& P. E. GARCÍA. 2018. Characterisation and reactivty continuum of dissolved organic matter in forested headwater catchments of Andean Patagonia. Freshwater Biology, 63 (9): 1049-1062.

GARCÍA, P., M. C. DIÉGUEZ \& C. P. QUEIMALIÑOS. 2015a. Landscape integration of North Patagonian mountain lakes: a first approach using characterization of dissolved organic matter. Lakes \& Reservoirs: Research and Management, 20: 1-14.

GARCÍA, R. D., M. REISSIG, C. P. QUEIMALIÑOS, P. E. GARCÍA \& M. C. DIÉGUEZ. 2015b. Climate-driven terrestrial inputs in ultraoligotrophic mountain streams of Andean Patagonia revealed through chromophoric and fluorescent dissolved organic matter. Science of the Total Environment, 521-522: 280-292. DOI: 10.1016/j.scitotenv.2015.03.102

GILLOOLY, J. F., J. H. BROWN, G. B. WEST, V. M. SAVAGE \& E. L. CHARNOV. 2001. Effects of size and temperature on metabolic rate. Science, 293: 2248-2251.

GORDON, N. D., T. A. MCMAHON, C. J. GIPPEL \& R. J. NATHA. 2004. Stream Hydrology An Introduction for Ecologist. John Wiley \& Sons LTD. Chichester, England.

HAINES, A. T., B. L. FINLAYSON \& T. A. MCMAHON. 1988. A global classification river regimes. Applied Geography, 8: 255-272.

HOLKO, L., J. PARAJKA, Z. KOSTKA, P. SKODA \& G. BLÖSCHL. 2011. Flashiness of mountain streams in Slovakia and Austria. Journal of Hydrology, 405: 392-401. DOI: 10. 1016/j.jhydrol.2011.05.038

JEFFRIES, D. S., D. M. COX \& P. J. DILLON. 1979. Depresion of $\mathrm{pH}$ in lakes and streams in central Ontario during snowmelt. Journal of the Fisheries Research Board of Canada, 36: 640-646.

LALLEMENT, M., P. J. MACCHI, P. H. VIGLIANO, S. JUAREZ, M. RECHENCQ, $M$. BAKER, N. BOUWES \& T. A. CROWL. 2016. Rising from the ashes: Change in salmonid fish assemblages after 30 months of 
the Puyehue-Cordon Caulle volcanic eruption. Science of the Total Environment, 541: 1041-1051.

LAROCQUE, M., A. MANGIN, M. RAZACK \& O. BANTON. 1998. Contribution of correlation and spectral analyses to the regional study of a large karst aquifer (Charente, France). Journal of Hydrology, 205: 217-231.

LIKENS, G. E., F. H. BORMANN, N. M. JOHNSON \& R. S. PIERCE. 1967. The Calcium, Magnesium, Potassium, and Sodium Budgets for a Small Forested Ecosystem. Ecology, 48 (5): $772-785$.

LLIBOUTRY, L. 1998. Glaciers of Chile and Argentina. In: Satellite Image Atlas of Glaciers of the World: South America. R. S. Williams \& Ferrigno, J. G. (ed.). USGS Professional Paper.

MASIOKAS, M. H., R. VILLALBA, B. H. LUCKMAN, M. E. LASCANO, S. DELGADO \& P. STEPANEK. 2008. 20th-century recession and regional hydroclimatic changes in northwestern Patagonia. Global and Planetary Change, 60: 85-100.

MISERENDINO, M. L., M. A. KUTSCHKER, C. BRAND, L. LA MANNA, Y. C. DI PRINZIO, G. PAPAZIAN \& J. BAVA. 2016. Ecological Status of a Patagonian Mountain River: Usefulness of Environmental and Biotic Metrics for Rehabilitation Assessment. Environmental Management, 57 (6). DOI: 10.1007/s00267-016-0688-0

MISERENDINO, M. L., C. BRAND, L. B. EPELE, Y. C. DI PRINZIO, G. H. OMAD, M. ARCHANGELSKY, O. MARTÍNEZ \& M. A. KUTSCHKER. 2018. Biotic diversity of benthic macroinvertebrates at contrasting glacier-fed systems in Patagonia Mountains: The role of environmental heterogeneity facing global warming. Science of the Total Environment, 622-623: 152-163.

MODENUTTI, B. E., E. G. BALSEIRO, C. P. QUEIMALIÑOS, D. A. AÑON SUÁREZ, M. C. DIÉGUEZ \& R. J. ALBARIÑO. 1998. Structure and dynamics of food webs in Andean lakes. Lakes \& Reservoirs: Research and Management, 3 (3-4): 179-186. DOI: 10.1046/j.1440-1770.1998.00071.x

MOORE, R. D., G. RICHARD \& A. STORY.
2008. Electrical Conductivity as an Indicator of Water Chemistry and Hydrologic Process. Streamline Watershed Management Bulletin, 11 (2): 25-29.

NUÑEZ, M. N., S. A. SOLMAN \& M. F. CABRÉ. 2008. Regional climate change experiments over southern South America. II: Climate change scenarios in the late twenty-first century. Climate Dynamics, 32 (7-8): 1081-1095. DOI: 10.1007/s00382-008-0449-8 PARKER, B. P., D. E. SCHINDLER, K. G. BEATY, M. P. STAINTON \& S. E. M. KASIAN. 2009. Long-term changes in climate, streamflow, and nutrient budgets for first-order catchments at the Experimental Lakes Area (Ontario, Canada). Canadian Journal of Fisheries and Aquatic Sciences, 66: 1848-1863.

PARUELO, J. M., A. BELTRAN, E. JOBBÁGY, O. SALA \& R. GOLLUSCIO. 1998. The climate of Patagonia: general patterns and controls on biotic processes. Ecología Austral, 8 (2): 85-101.

PEDROZO, F. L., S. CHILLRUD, P. F. TEMPORETTI \& M. M. DIAZ. 1993. Chemical composition and nutrient limitation in rivers and lakes of northern Patagonian Andes (39.5 ${ }^{\circ}-42^{\circ}$ $\left.\mathrm{S} ; 71^{\circ} \mathrm{W}\right)$ (Rep. Argentina). Verhandlungen der Internationale Vereingung für Theoretische und Angewandte Limnologie, 25: 207-214.

PEEL, M. C., B. L. FINLAYSON \& T. A. MCMAHON. 2007. Updated world map of the Köppen-Geiger climate classification. Hydrology and Earth System Sciences, 4 (2): 439-473.

PELTIER, M. R., C. J. WILCOX \& D. C. SHARP. 1998. Technical Note: Application of the Box-Cox data transformation to animal science experiments. Journal of Animal Science, 78: 847-849.

POFF, N. L., J. D. ALLAN, M. B. BAIN, J. R. KARR, K. L. PRESTEGAARD, B. D. RICHTER, R. E. SPARKS \& J. C. STROMBERG. 1997. The Natural Flow Regime. Bioscience, 47 (11): 769-784.

QUEIMALIÑOS, C. P., M. REISSIG, M. C. DIÉGUEZ, M. ARCAGNI, S. RIBEIRO GUEVARA, L. CAMPBELL, C. SOTO 
CÁRDENAS, R. RAPACIOLI \& M. A. ARRIBÉRE. 2012. Influence of precipitation, landscape and hydrogeomorphic lake feature on pelagic allochthonous indicators in two connected ultraoligotrophic lakes of North Patagonia. Science of the Total Environment, 427-428: 219-228. DOI: 10.1016/j.scitotenv. 2012.03.085

SAS INSTITUTE INC. 2013. SAS/STAT® 13.1 User's Guide. SAS Institute Inc. Cary, NC.

SATTI, P., M. J. MAZZARINO \& M. GOBBI. 2003. Soil $N$ dynamics in relation to leaf litter quality and soil fertility in north-western Patagonian forests. Journal of Ecology, 91: 173-181.

SATTI, P., M. J. MAZZARINO, L. ROSELLI \& P. CREGO. 2007. Factors affecting soil $\mathrm{P}$ dynamics in temperate volcanic soils of southern Argentina. Geoderma, 139: 229-240.

STUBBLEFIELD, A. P., J. E. REUTER, R. A. DAHLGREN \& C. R. GOLDEMAN. 2007. Use of turbidometry to characterize suspended sediment and phosphorus fluxes in the Lake Tahoe basin, California, USA. Hydrological Processes, 21: 281-291. DOI: 10.1002/ hyp. 6234

SUEKER, J. K., J. N. RYAN, C. KENDALL \& R. D. JARRETT. 2000. Determination of hydrologic pathways during snowmelt for alpine/subalpine basins, Rocky Mountains National Park, Colorado. Water Resources Research, 36: 63-75.

TATE, K. W. \& M. J. SINGER. 2013. Timing, Frecuency of Sampling Affect Accuracy of
Water-Quality Monitoring. California Agriculture, 53 (6): 44-48. DOI: 10.3733/ca. v053n06p44

TEMPORETTI, P. F. 2006. Efecto a largo plazo de los incendios forestales en la calidad del agua de dos arroyos en la sub-región Andino-Patagónica, Argentina. Ecología Austral, 16 (2): 157-166.

TOJA SANTILLANA, J. 2005. Característica de los distintos tipos de ecosistemas acuáticos. In: Manual de Limnología. D. d. B. V. y. Ecología (ed.): 808-851. Universidad de Sevilla. Sevilla, España.

WELCH, E. B., J. M. JACOBY \& M. W. CHRISTOPHER. 1998. Stream Quality. In: River Ecology and Management. R. J. Naiman \& Bilby, R. E. (ed.): 69-96. Springer. New York, USA.

WILLIAMS SUBIZA, E. A. \& C. BRAND. 2018. Short-term effect of wildfire on Patagonian headwater streams. International Journal of Wildland Fire, 27: 457-470.

WILLIAMSON, T. N. \& C. G. CRAWFORD. 2011. Estimation of Suspended Sediment Concentration from Total Suspended Solids and Turbidity Data for Kentucky, 1978-1995. Journal of American Water Resources Association, 47: 739-749. DOI: $10.1111 / \mathrm{j} .1752-$ 1688.2011.00538.x

ZIEMER, R. R. \& T. E. LISLE. 1998. Hydrology. In: River Ecology and Management, Lessons from the Pacific Coastal Ecoregion. R. J. Naiman \& Bilbly, R. E. (ed.): 43-68. Springer. New York, USA. 